\title{
SOWS AND PIGLETS THERMAL COMFORT: A COMPARATIVE STUDY OF THE TILES USED IN THE FARROWING HOUSING
}

Doi:http://dx.doi.org/10.1590/1809-4430-Eng.Agric.v36n6p996-1004/2016

\section{SIVANILZA T. MACHADO ${ }^{1 *}$, IRENILZA DE A. NÄÄS ${ }^{2}$, JOÃO G. M. DOS REIS ${ }^{2}$, FABIANA R. CALDARA ${ }^{3}$, RODRIGO C. SANTOS ${ }^{3}$}

\author{
$1 *$ Corresponding author. Paulista University/ São Paulo - SP, Brazil. E-mail: sivanilzamachado@ifsp.edu.br
}

\begin{abstract}
The global animal production is increasing as expected to meet world demand for food, especially for meat products. This research aimed to investigate the effect of two types of roofs (clay and fiber-cement tiles) in a tropical area on the thermal comfort of farrowing sows and piglets. Twelve sows and forty-eight piglets were observed during summer in the Southeast region of Brazil. Climate variables, thermal comfort and surface temperature (sows and piglets) were assessed. The type of roofs clearly affected the piglets' surface temperature during all studied periods, but the results were not similar in the sows' surface temperature. Temperature and humidity index found was high in the building with fiber-cement tiles. The pen location in the housing also influenced the piglet surface temperature. Controlling temperature fluctuation in piglet housing is crucial; therefore, providing adequate rearing environment in tropical condition might help pig productivity as well as farmer profitability.
\end{abstract}

KEYWORDS: pig production, roof material, surface temperature, thermal comfort, tropical conditions.

\section{INTRODUCTION}

The demand for global food has increased the investment in agriculture in several countries. To meet the demand for protein animal, the production process has explored different types of production systems that represent a balance between animal welfare, rural productivity and costs of production. The intensive systems of pig production require planning for each phase of production, such as breeding, farrowing, weaning and finishing especially in tropical conditions. Brazilian weather conditions imply a difficult indoor condition to livestock production (RENAUDEAU et al., 2012). Global animal production in tropical and subtropical areas showed an increased during the last 20 years (RENAUDEAU et al., 2012; ZHANG et al., 2012). Brazilian swine production is mostly concentrated in the tropical and subtropical regions of the country. The three main Brazilian regions are South with 50\%, Southeast with $18 \%$ and Midwestern with $13 \%$ (BRAZILIAN ASSOCIATION OF ANIMAL PROTEIN, 2015). The hot climatic condition is the main limiting factor of pig production and performance. Acute or chronic heat stress lead to high mortality and low yield during swine production process (RENAUDEAU et al., 2012).

The planning of pig production facilities should consider several conditions inherent of the animal characteristics aiming the maximum performance during the production process. Adequate spacing, walls height, flooring area, air quality, adequate water and food supply, are examples of some criteria to assure good animal performance mainly in tropical areas (BAXTER et al., 2011; ZHANG et al., 2012; FRASER et al., 2013). Farmers are always willing to reduce building costs and construction time, and sometimes some building materials used are not appropriate to swine production. The roof material plays an important role in tropical countries due to the solar energy input through the roof. This variable directly affects the pigs thermal comfort during all production stages particularly in the farrowing phase, as sows and piglets show different biological needs. As suggest by BAXTER et al. (2011) the agricultural practices should be based on biological needs to adopt the appropriate design criteria for farrowing and lactation system, and to provide proper welfare for both. Providing thermal comfort in farrowing is mostly challenging for farmers because

\footnotetext{
${ }^{2}$ Paulista University/ São Paulo-SP, Brazil.

${ }^{3}$ Federal University of Grande Dourados/ Dourados-MS, Brazil.

Received in: 12-17-2015

Accepted in: 6-24-2016
} 
farrowing sows and piglets required different temperature levels. Temperatures of 16 to $25^{\circ} \mathrm{C}$ are most comfortable for sows while temperatures as high as $32{ }^{\circ} \mathrm{C}$ are comfortable for piglets (DONG et al., 2001). Building materials used in floor, walls and roofs can facilitate reaching the thermal comfort control to sows and piglets. Roofs and walls used in the rural building are the main surfaces to protect animals from sun radiation. The tiles used in roofs of farrowing buildings are usually gray fiber-cement tiles, colonial clay tiles, and French clay tiles (ABREU et al., 2011). The animals productivity depends on the thermal comfort, and ultimately to animal welfare. The fiber-cement tile is usually used in rural building for animals due to be easy to handle and low cost (SHIRAKAWA et al., 2014).

Livestock production is a complex task, and it involves many variables that interact with the animal. It is essential to understand the animal, the physiological and behavioral needs, and the adaptive biological process (genetics, acclimatization, habit, and conditioning) when adopting a proper housing system based on the biological needs (BAÊTA \& SOUZA, 2010; BAXTER et al., 2011). The animal under aversive environment shows a stressful response and present unnatural behavior. According to FRASER et al. (2013), the animal behavior is affected by the environmental quality and the quantity of the space. Animals have many types of response to adapt and survival under an aversive condition. The adaptation is defined as the animal ability to adjust their system to environment condition saving their reproductive and growing rate, showing a minimum loss in live weight and mortality rate, and disease resistance (BAÊTA \& SOUZA, 2010). Thus, the coordinated expression representing the sows and piglets, as well as their interaction with the housing environment, is essential to reduce mortality rate in farrowing (BAXTER et al., 2011).

The assessment of whether the housing environment is appropriate to the animal and provides proper welfare conditions is a challenge. There are some techniques used in livestock production, more or less invasive. For instance, the thermal comfort can be assessed using an index value that represents the influence of heat exchange using a physiological measurement (rectal, cloacal and skin temperatures, and respiratory rate) (RENAUDEAU et al., 2012).

The present study aimed to investigate the differences in the thermal comfort of farrowing sows and piglets housed in two types of roofs, of clay and fiber-cement tiles.

\section{MATERIAL AND METHODS}

The present study was conducted during the summer in February 2015. The observation field is located in Southeastern Brazil with 20 50'56' 'S latitude, $41^{\circ} 06^{\prime} 46^{\prime}$ 'W longitude, and $21 \mathrm{~m}$ of altitude. The average of the outdoor air temperature was $29.1{ }^{\circ} \mathrm{C}$, and relative humidity (RH) was 54\%. The climate with tropical characteristics shows two distinct seasons, dry from AprilSeptember and rainy from October-March (INSTITUTO CAPIXABA DE PESQUISA, ASSISTÊNCIA TÉCNICA E EXTENSÃO RURAL, 2015).

\section{Animals, husbandry, and observation procedures}

A total of 12 sows and 48 piglets (a hybrid from Landrace and Large White genetic strains) were observed during the morning $(9 \mathrm{~h} 00 \mathrm{~min}<10 \mathrm{~h} 00 \mathrm{~min}, 10 \mathrm{~h} 00 \mathrm{~min}<11 \mathrm{~h} 00 \mathrm{~min}$ and $11 \mathrm{~h} 00 \mathrm{~min}<$ 12h00min). A data logger (Testo model 174H, Testo AG, Lenzkirch, Germany) was installed in the geometric center of the farrowing pen to record the variation of air temperature $\left(\mathrm{T}_{\mathrm{a}}\right)$ and relative humidity (RH) every five minutes (MCGLONE et al., 2014). The sows' surface temperature (SST) and piglets' surface temperature (PST) were assessed using a thermal infrared camera (Testo model 875, Testo AG, Lenzkirch, Germany). The thermal images were registered in three stages, as follows $1=$ started at $9 \mathrm{~h} 00 \mathrm{~min}$ and concluded at $9 \mathrm{~h} 30 \mathrm{~min} ; 2=$ started at $10 \mathrm{~h} 00 \mathrm{~min}$ and concluded at $10 \mathrm{~h} 30 \mathrm{~min}$; and 3 = started at $11 \mathrm{~h} 00 \mathrm{~min}$ and concluded $11 \mathrm{~h} 30 \mathrm{~min}$ ).

In the present study, we consider two types of roofs (clay tile and fiber-cement tile). The position of the sows in the observed pens is shown in FIGURE 1. 


\begin{tabular}{|c|c|c|c|c|c|c|}
\hline \multirow{8}{*}{$\begin{array}{l}F \\
\overline{0} \\
z\end{array}$} & \multicolumn{5}{|c|}{ East } & \\
\hline & Position & & ents: $\mathrm{C}=\mathrm{Cl}$ & nd $F=$ Fiber & ent & \\
\hline & \multirow{2}{*}{ Right } & \multicolumn{2}{|c|}{ S5 } & \multicolumn{2}{|c|}{ S6 } & \\
\hline & & $\mathrm{C} \#(++++)$ & $\mathrm{F} \#(++++)$ & $\mathrm{C} \#(++++)$ & $\mathrm{F} \#(++++)$ & \\
\hline & \multirow{2}{*}{ Center } & \multicolumn{2}{|c|}{ S3 } & \multicolumn{2}{|c|}{ S4 } & \\
\hline & & $\mathrm{C} \#(++++)$ & $\mathrm{F} \#(++++)$ & $\mathrm{C} \#(++++)$ & $\mathrm{F} \#(++++)$ & \\
\hline & \multirow{2}{*}{ Left } & \multicolumn{2}{|c|}{ S1 } & \multicolumn{2}{|c|}{ S2 } & \\
\hline & & $\mathrm{C} \#(++++)$ & $\mathrm{F} \#(++++)$ & $\mathrm{C} \#(++++)$ & $\mathrm{F} \#(++++)$ & \\
\hline \multicolumn{6}{|c|}{ West } & \\
\hline
\end{tabular}

FIGURE 1. The position of the sows (\#) and piglets (+) in the observed pens.

The following variables were analyzed: sows' surface temperature (SST), piglets' surface temperature (PST), air temperature $\left(\mathrm{T}_{\mathrm{a}}\right)$, relative humidity $(\mathrm{RH})$, and temperature-humidity index (THI). The average value of surface temperature on the sows' body (40 points distributed along the sows' body) and on piglets' body (20 points distributed along the piglets' body) was adopted to calculate the sows and the piglets surface temperature (SST and PST) (FIGURE 2).
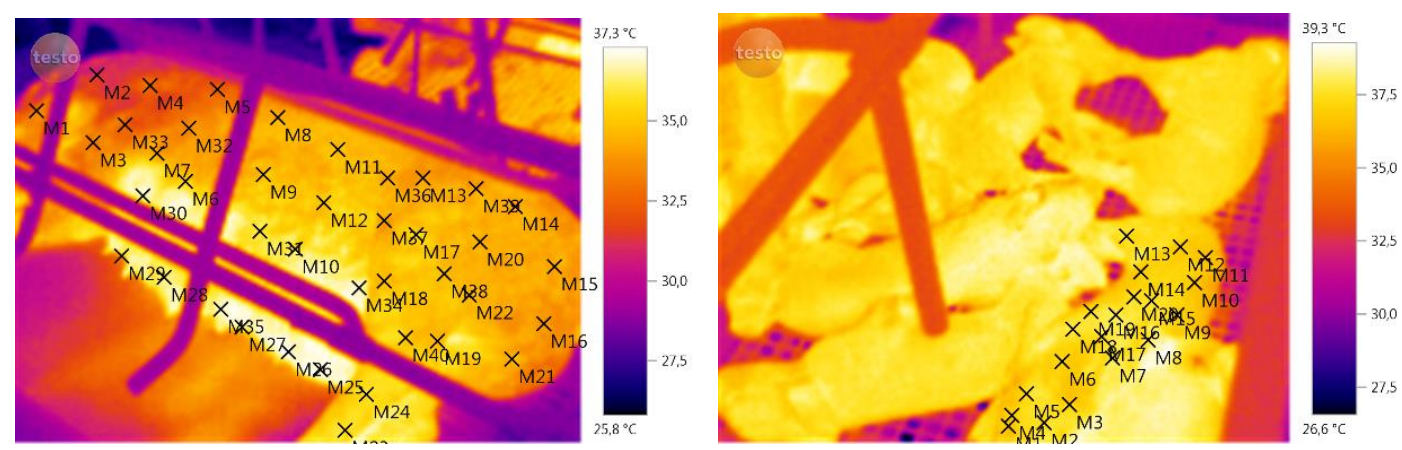

FIGURE 2. Thermal infrared image of the sows and the piglets in the farrowing pen. The emissivity of the pig skin surface $=0.95$ (SOERENSEN et al., 2014).

To measure the temperature humidity index (THI), [eq. (1)] was applied, as proposed by BUFFINGTON et al. (1982).

$$
T H I=(0.8 * T a)+R H\left[\frac{T a-14.3}{100}\right]+46.3
$$

where,

$$
\begin{aligned}
& \mathrm{T}_{\mathrm{a}}=\text { air temperature }\left({ }^{\circ} \mathrm{C}\right) \text {, and } \\
& \mathrm{RH}=\text { relative humidity }(\%) .
\end{aligned}
$$

\section{Statistical analysis}

A normality test was applied to all registered variables. The sows'surface temperature and piglets (SST and PST) was analyzed using the ANOVA. The air temperature $\left(\mathrm{T}_{\mathrm{a}}\right)$, relative humidity (RH) and temperature humidity index (THI) were analyzed using GLM (General Linear Models). The correlation test was applied to identify the relation between the sows'surface temperature and piglets with THI. Tukey test was applied to mean values of the registered variables using a significance of 95\%. The SAS procedures PROC UNIVARIATE, PROC ANOVA, PROC GLM and PROC CORR, were applied to data (STATISTICAL ANALYSIS SYSTEM, 2014). 
To assess the thermal comfort of piglets and sows the mathematical models, eqs. (2) and (3) were applied:

$$
\begin{aligned}
& Y i j r=\mu+T i+S j+\varepsilon i j r \\
& Y i r=\mu+T i+\varepsilon i r
\end{aligned}
$$

where,

$Y_{i j r}=$ piglets' surface temperature (PST), $\mathrm{T}_{\mathrm{a}}, \mathrm{RH}$ and THI $(i=1$ and $2 ; j=1,2,3,4,5$ and $6 ; r=4)$;

$Y_{i r}=$ sows' surface temperature $(\mathrm{SST}), \mathrm{T}_{\mathrm{a}}, \mathrm{RH}$ and THI $(i=1$ and $2 ; r=6)$;

$\mu=$ general average;

$T_{i}=$ effect of the type of roofs $i$;

$S_{j}=$ effect of sows and piglets position $j$;

$\varepsilon_{i j r}=$ random error $i j r$.

\section{RESULTS AND DISCUSSION}

The variables $\mathrm{T}_{\mathrm{a}}, \mathrm{RH}$, and THI differed $(p<0.05)$ in relation to the building with clay tile and fiber-cement tile. The THI with the fiber-cement tiles was higher (1.0) than that of the clay tile. The result is in agreement with SARUBBI et al. (2012), who found an increase on THI of 3.0 in pigs reared under building using the roof of fiber-cement tiles, compared to clay tile during spring. In the present study, the variation of the $\mathrm{T}_{\mathrm{a}}$ from clay tile was $3.0^{\circ} \mathrm{C}$ and $\mathrm{RH} 9.5 \%$. The fiber-cement tiles showed a change of $\mathrm{T}_{\mathrm{a}}$ of the $3.6^{\circ} \mathrm{C}$ and $\mathrm{RH}$ was $4.9 \%$ (TABLE 1). The higher the moisture in the material, the higher the thermal conductivity influencing the temperature range (AL-HOMOUND, 2005). The fiber-cement tile indicates that an extreme discomfort in the summer or hot period can occur. It is then recommended that building using fiber-cement tiles should have a layer of coating to mitigate the sun radiation and improve thermal comfort (SHIRAKAWA et al., 2014).

The heavier the pigs are, the more they are susceptible to heat stress due to a lower ability to dissipate heat (RENAUDEAU et al., 2012). GRANDIN (2013) alerts that heavy pigs under environment above $27{ }^{\circ} \mathrm{C}$ of temperature and $80 \%$ of relative humidity are in critical condition. The thermal comfort in the farrowing pens is a challenge that involves balancing of biological needs of the sows and piglets, as well as to meet the thermal requirements of the piglets while safeguarding sow comfort (BAXTER et al., 2011; CALDARA et al., 2014). Heat stress is the primary source of losses in pig production due the animal's responses to the variation of climate condition that they are exposed (RENAUDEAU et al., 2011).

TABLE 1. Average values for air temperature $\left(\mathrm{T}_{\mathrm{a}},{ }^{\circ} \mathrm{C}\right)$, relative humidity $(\mathrm{RH}, \%)$ and temperature humidity index (THI) during the studied period.

\begin{tabular}{ccccc}
\hline Roof material & Period (h min) & \multicolumn{3}{c}{ Variables } \\
\hline & 9h00min $<10 \mathrm{~h} 00 \mathrm{~min}$ & $\mathrm{~T}_{\mathrm{a}}$ & $\mathrm{RH}$ & $\mathrm{THI}$ \\
Clay & & $29.4 \pm 0.4^{\mathrm{b}}$ & $51.8 \pm 1.3^{\mathrm{b}}$ & $77.6 \pm 0.4^{\mathrm{b}}$ \\
Fiber-cement & & $30.1 \pm 0.3^{\mathrm{a}}$ & $59.4 \pm 0.7^{\mathrm{a}}$ & $80.4 \pm 0.5^{\mathrm{a}}$ \\
& \multirow{2}{*}{ 10h00min $<11 \mathrm{~h} 00 \mathrm{~min}$} & $\mathrm{~T}_{\mathrm{a}}$ & $\mathrm{RH}$ & $\mathrm{THI}$ \\
Clay & & $31.3 \pm 0.5^{\mathrm{b}}$ & $46.5 \pm 1.7^{\mathrm{b}}$ & $79.2 \pm 0.5^{\mathrm{b}}$ \\
Fiber-cement & & $32.1 \pm 0.4^{\mathrm{a}}$ & $56.1 \pm 3.8^{\mathrm{a}}$ & $81.9 \pm 0.3^{\mathrm{a}}$ \\
& \multirow{2}{*}{ 11h00min $<12 \mathrm{~h} 00 \mathrm{~min}$} & $\mathrm{~T}_{\mathrm{a}}$ & $\mathrm{RH}$ & $\mathrm{THI}$ \\
Clay & & $32.4 \pm 0.4^{\mathrm{b}}$ & $42.6 \pm 2.0^{\mathrm{b}}$ & $80.0 \pm 0.4^{\mathrm{b}}$ \\
Fiber-cement & & $33.7 \pm 0.3^{\mathrm{a}}$ & $54.5 \pm 0.5^{\mathrm{a}}$ & $83.8 \pm 0.4^{\mathrm{a}}$ \\
\hline
\end{tabular}

Means with the same letter in the same column do not differ by the Tukey test $(p>0.05)$.

The fiber cement tile showed an average of sows' surface temperature of more $0.79{ }^{\circ} \mathrm{C}$ than the clay tile for the period analyzed. We observed a variation of the SST of $1.96{ }^{\circ} \mathrm{C}\left(0.65^{\circ} \mathrm{C} \mathrm{h}^{-1}\right)$ 
and $1.71{ }^{\circ} \mathrm{C}\left(0.57{ }^{\circ} \mathrm{C} \mathrm{h}^{-1}\right)$ for clay and fiber-cement respectively. Also, the average of PST was 0.97 ${ }^{\circ} \mathrm{C}$ for fiber-cement tiles, and the variation was $1.45^{\circ} \mathrm{C}$ and $0.53{ }^{\circ} \mathrm{C}$ for clay and fiber cement tiles, respectively (TABLE 2). Although the piglets showed an average of surface temperature higher than the sows, the variation was small. These variations of surface temperature were influenced by the air temperature and RH gradients that were present during the analyzed periods. Many studies present concerns regarding the impact of heat stress on sows' productivity (DONG et al., 2001; BLOEMHOF et al., 2008; BAXTER et al., 2011; RENAUDEAU et al., 2012). A previous study by WILLIAMS et al. (2013) indicates that despite the sows were in heat stress and had reduced feed intake, the effect on piglet performance was small, as the condition did not impact on the sows' milk production. Reducing feed intake under heat stress is considered an adaptation response of the pigs to reducing heat production and it has a direct adversnegative effect on growth performance (RENAUDEAU et al., 2011). However, cold weather temperature and wind chills can be dangerous to pigs' production (GRANDIN, 2013). The suggestion to pig production based on animal welfare principles is to adopt environmental system control independent of the climate condition of the region of hot or cold weather.

TABLE 2. Average values for superficial temperature $\left(\mathrm{ST},{ }^{\circ} \mathrm{C}\right)$, for each studied period.

\begin{tabular}{|c|c|c|c|c|c|c|c|}
\hline \multirow[b]{2}{*}{ Roofs } & \multicolumn{2}{|c|}{ Sow* } & \multicolumn{5}{|c|}{ Piglet } \\
\hline & Clay & Fiber-cement & $\mathrm{CV}$ & Clay & Fiber- cement & $\mathrm{n} \quad \mathrm{CV}$ & $P$ \\
\hline $\mathrm{ST}_{09}$ & $34.58 \pm 0.6^{\mathrm{b}}$ & $35.57 \pm 0.6^{\mathrm{a}}$ & 0.8 & $* * 35.80 \pm 0.8^{\mathrm{b}}$ & $37.17 \pm 0.4^{\mathrm{a}}$ & 471.5 & $* *$ \\
\hline $\mathrm{ST}_{10}$ & $35.82 \pm 0.3$ & $36.47 \pm 0.6$ & 1.5 & ns $36.36 \pm 1.0^{b}$ & $37.45 \pm 0.9^{\mathrm{a}}$ & 432.3 & ** \\
\hline $\mathrm{ST}_{11}$ & $36.54 \pm 0.7$ & $37.28 \pm 0.5$ & 1.5 & ns $37.25 \pm 0.5 b$ & $37.70 \pm 0.8^{\mathrm{a}}$ & 451.6 & \\
\hline
\end{tabular}

${ }^{*}$ Total $=12$ sows; Means with the same letter in the same row did not differ by Tukey Test $(p>0.05) ; \mathrm{CV}=$ Coefficient of variation; $P=p$-value $\left({ }^{* *} p<0.01,{ }^{*} p<0.05,{ }^{\text {ns }} p>0.05\right)$.

For each degree of temperature increase $\left(\mathrm{T}_{\mathrm{a}}\right)$ in the farrowing pen with clay tile, an increase of $0.26{ }^{\circ} \mathrm{C}$ and $0.77{ }^{\circ} \mathrm{C}$ was observed at the surface temperature of piglets (PST) at $10 \mathrm{~h} 00 \mathrm{~min}$ and $11 \mathrm{~h} 00 \mathrm{~min}$, respectively. In the farrowing pen with fiber-cement tiles, the values were 0.15 and 0.19 ${ }^{\circ} \mathrm{C}$, respectively. In addition, the sows'surface temperature (SST) showed an increase of 0.66 and $0.61{ }^{\circ} \mathrm{C}$ for each $\mathrm{T}_{\mathrm{a}}$ increase in the farrowing pens with clay tile, and 0.60 and $0.51{ }^{\circ} \mathrm{C}$ in the farrowing pens with fiber-cement tiles at $10 \mathrm{~h} 00 \mathrm{~min}$ and $11 \mathrm{~h} 00 \mathrm{~min}$, respectively. After three hours, the SST showed an increase of approximately $2{ }^{\circ} \mathrm{C}$ and the PST of $1.5^{\circ} \mathrm{C}$ in the pens with clay tile, and $1.7^{\circ} \mathrm{C}$ and $0.5^{\circ} \mathrm{C}$ in the pens with fiber-cement tiles, respectively (FIGURE 3). These results agree with CALDARA et al. (2014), that identified the direct influence of the ambient on piglet body temperature.

According to preceding study, WILLIAMS et al. (2013), the heat stress occurs when the ambient temperature exceeds the upper critical temperature (UCT) of the sow's thermal-neutral zone. In the current study, the THI increased 2.37 under clay tile (average 79) and 3.37 under fiber cement tile (average 82) during the studied stages. BARBARI \& CONTI (2009) suggest that producers should have special care with THI values above 75 and within the range of 79 to 83 that represents a critical condition for pigs. Following the recommendation in this past study by BARBARI \& CONTI (2009), sows and piglets are thermally uncomfortable in both rooms (clay and fiber-cement tiles), and this condition is critical to pig production. THI values for pigs were estimated during spring in an environment with clay $(73 \pm 4.0)$ and fiber-cement tiles $(76 \pm 4.0)$ (SARUBBI et al., 2012). In the present research, just pigs reared in pens with clay tile were in thermal comfort. Although, BLOEMHOF et al. (2008) defined UCT as the temperature above that reproductive performance declines, and the authors estimated the UCT for sows during the breeding period to be around $20{ }^{\circ} \mathrm{C}$. Studying the sows' performance in moderate climate WEGNER et al. (2014) showed a summer average farrowing pen temperature, RH and THI of $23.8{ }^{\circ} \mathrm{C}, 66 \%$ and 69 respectively. When sows are comfortable, the intake energy is used for the production of milk and fat tissue (RENAUDEAU et al., 2012). 


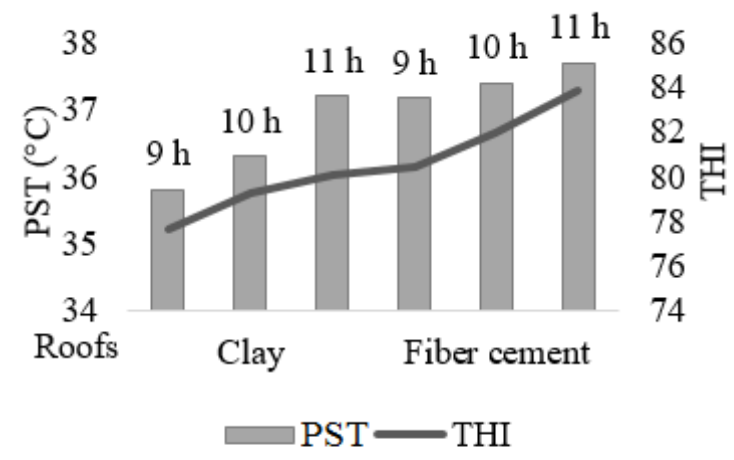

a

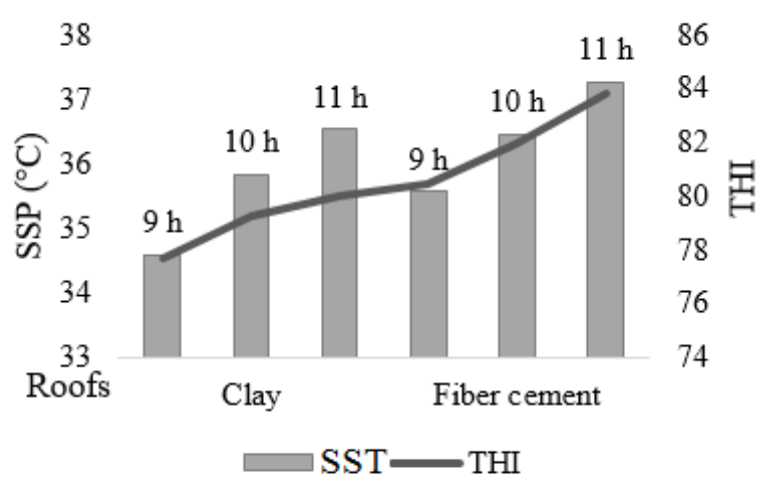

$\mathrm{b}$

FIGURE 3. Average values of the piglet' surface temperature (PST, ${ }^{\circ} \mathrm{C}$ ) (a) and the sow surface temperature (SST, $\left.{ }^{\circ} \mathrm{C}\right)(\mathrm{b})$, and the temperature humidity index between two roofs in each studied period.

The temperature-humidity index showed a positive correlation with the sows and piglets' surface temperature for the analyzed period. The correlation of THI with SST at 9h00min was high ( $p<0.05)$, as well as with PST at 9h00min and 10h00min $(p<0.01)$; and at 11h00min $(p<0.05)$ (TABLE 3). In the pig's productive process, the control of environmental temperature related to the extreme weather is vital for achieving the animal thermal comfort (FRASER et al., 2013). The proper rearing environment leads to good welfare condition and contributes to pig homeostasis (BAÊTA \& SOUZA, 2010). However, FRASER et al. (2013) indicate that not only the weather condition might be controlled, but also other variables related to pigs health (diseases and parasites).

TABLE 3. The coefficient of correlation for THI and surface temperature (ST) of sows and piglets, per each period.

\begin{tabular}{ccccccc}
\hline Period & \multicolumn{2}{c}{9 9h00min } & \multicolumn{2}{c}{$10 \mathrm{~h} 00 \mathrm{~min}$} & \multicolumn{2}{c}{$11 \mathrm{~h} 00 \mathrm{~min}$} \\
\hline ST & SST & PST & SST & PST & SST & PST \\
THI & $0.6361^{*}$ & $0.7259^{* *}$ & $0.5371^{\text {ns }}$ & $0.4931^{* *}$ & $0.5336^{\text {ns }}$ & $0.3279^{*}$ \\
\hline \multicolumn{2}{l}{ ST= surface temperature; ${ }^{* *} p<0.01 ;{ }^{*} p<0.05$; $^{\text {ns }} p>0.05}$.
\end{tabular}

In some cases, the use of ventilation systems is needed to modify the environmental condition near the sows, providing a proper area for the piglets to the group when they feel cold (BAXTER et al., 2011; WEGNER et al., 2014). WEGNER et al. (2014) observed that rearing temperature was associated with the number of weaned piglets. Animals under tropical and sub-tropical areas that are exposed to chronic heat stress presented reduced performance, when compared to animals reared under moderate heat conditions, and acute exposure in a short-term (BAÊTA \& SOUZA, 2010; RENAUDEAU et al., 2012). A pig farmer in tropical areas may alleviate sows heat stress by providing appropriate cooling devices during the lactation period (WILLIAMS et al., 2013).

Considering the solar orientation (East-West at 9h00min, FIGURE 1) a difference of $0.76{ }^{\circ} \mathrm{C}$ on the surface temperature of piglets located on the right side of the pen (S5/S6) was found. A difference of $0.32{ }^{\circ} \mathrm{C}$ was observed in the surface temperature of the piglets situated on the right side of the pen (S5/S6) to the center (S3/S4). A total of $0.44{ }^{\circ} \mathrm{C}$ in the surface temperature of the piglets was found in those located in the center on the left side of the pen (S1/S2). At 10h00min it was noticed a decrease on PST $\left(0.73{ }^{\circ} \mathrm{C}\right.$, from S5/S6 to S1/S2) and $1.11{ }^{\circ} \mathrm{C}$ (from S5/S6 to S3/S4). It was also found an increase of $0.38{ }^{\circ} \mathrm{C}$ (from S3/S4 to S1/S2). At $11 \mathrm{~h} 00 \mathrm{~min}$ it was found an increase of $0.22{ }^{\circ} \mathrm{C}$ in the surface temperature of the piglets (from S5/S6 to S1/S2) and $0.35{ }^{\circ} \mathrm{C}$ (from S3/S4 to $\mathrm{S} 1 / \mathrm{S} 2$ ), a decrease of $0.12{ }^{\circ} \mathrm{C}$ in the surface temperature of the piglets located in $\mathrm{S} 5 / \mathrm{S} 6$ to $\mathrm{S} 3 / \mathrm{S} 4$, as seen in TABLE 4. 
TABLE 4. Average values for the surface temperature of piglets (PST, ${ }^{\circ} \mathrm{C}$ ) by the position of farrowing sows, per each period.

\begin{tabular}{cccccccccc}
\hline Period & \multicolumn{3}{c}{$9 \mathrm{~h} 00 \mathrm{~min}$} & \multicolumn{3}{c}{$10 \mathrm{~h} 00 \mathrm{~min}$} & \multicolumn{3}{c}{$11 \mathrm{~h} 00 \mathrm{~min}$} \\
\hline Position & $\mathrm{n}$ & PST & SD & $\mathrm{n}$ & PST & SD & $\mathrm{n}$ & PST & SD \\
S1 & 8 & $35.85^{\mathrm{c}}$ & 1.2 & 8 & $36.78^{\mathrm{ab}}$ & 1.6 & 7 & $37.42^{\mathrm{ab}}$ & 0.7 \\
S2 & 8 & $36.27^{\mathrm{bc}}$ & 0.9 & 8 & $37.42^{\mathrm{a}}$ & 1.1 & 8 & $37.20^{\mathrm{b}}$ & 0.4 \\
S3 & 8 & $36.30^{\mathrm{bc}}$ & 1.1 & 8 & $37.20^{\mathrm{a}}$ & 0.5 & 8 & $37.65^{\mathrm{ab}}$ & 0.6 \\
S4 & 7 & $36.70^{\mathrm{ab}}$ & 0.6 & 3 & $37.76^{\mathrm{a}}$ & 0.5 & 8 & $37.67^{\mathrm{ab}}$ & 0.6 \\
S5 & 8 & $36.80^{\mathrm{ab}}$ & 0.7 & 8 & $36.02^{\mathrm{b}}$ & 0.9 & 8 & $37.07^{\mathrm{b}}$ & 0.8 \\
S6 & 8 & $36.85^{\mathrm{a}}$ & 0.6 & 8 & $36.71^{\mathrm{ab}}$ & 0.7 & 6 & $38.00^{\mathrm{a}}$ & 0.3 \\
\hline
\end{tabular}

Means with the same letter in the same column do not differ by Tukey Test ( $p>0.05)$. SD $=$ Standard deviation; total piglets: 9h00min $=47$, $10 \mathrm{~h} 00 \mathrm{~min}=43,11 \mathrm{~h} 00 \mathrm{~min}=45$.

The variation of temperature in the different location of pigs in the observation field is necessary to identify the heat point and to create strategies to alleviate the heat stress of pigs. In the present study, we determined that the sun direction in the morning (sun rising) to the afternoon (sunset), increased the pigs surface temperature that were in the places at the right side of the building, more than in the pigs at the center or the left side, as well as the sun moving changed the surface temperature of pigs across the hours (from 9h00min to 11h00min). Therefore, providing natural or artificial shading for pigs located near the direct solar radiation incidence might improve the thermal comfort and productivity. Despite the effect of rearing temperature on pig performance identified by RENAUDEAU et al. (2011), the authors observed that the genetic potential plays a significant role in pig production.

Confined rearing environment should allow comfortable resting, safe and movement to perform behaviors of their natural repertoire (FRASER et al., 2013). In the tropical condition, reared animals are usually subjected to temperature fluctuation throughout the day and across the days (RENAUDEAU et al., 2011), that constrains pigs physiological and behavior performance. In China, pig intensive production is concentrated in the South and Southwest regions, where the mean outside air temperature is typically $36.0{ }^{\circ} \mathrm{C}$, and the relative humidity is $75 \%$ in the afternoon, during the hottest month (DONG et al., 2001). In this region, some farmers suspend the activity during the hottest months to avoid economic loss. Even in the countries of North America, Australia and Europe located in temperate zones, during the hot summer months, the heat stress is a challenge. In this period, there is an increase in mortality, reduced performance, impacting in economic losses and lack in animal welfare (RENAUDEAU et al., 2012). Health problems also are related by ZHANG et al. (2012), due to the appearance of common diseases in intensive pig production under tropical and subtropical condition.

Heat waves during summer in Southern Europe has been more frequent, leading to significant losses in productivity (BARBARI \& CONTI, 2009). Traditionally, farmers had adopted the ventilation system, and they had utilized the source of the natural ventilation. Several studies suggest cooling strategies to provide thermal comfort for pigs, mainly for gestating and farrowing sows (AL-HOMOUND, 2005; BARBARI \& CONTI, 2009; RENAUDEAU et al., 2012). Cooling systems have been used more often in chicken production than in pig production, in Brazil. According to AL-HOMOUND (2005), the appropriate cooling equipment for animal production requires a large use of energy. Also, the thermal performance of the system depends on the buildings heat exchange characteristics (AL-HOMOUND, 2005). In rural housing under tropical climate, the roofs are the main part receiving the direct solar radiation. Increasing the roof reflectivity might be an efficient way to reduce the effects of solar radiation in the internal environment (SHIRAKAWA et al., 2014).

\section{CONCLUSIONS}

Despite the type of roof, it did not affect the sows' surface temperature at $10 \mathrm{~h} 00 \mathrm{~min}$ and at $11 \mathrm{~h} 00 \mathrm{~min}$, the influence of the climate condition $\left(\mathrm{T}_{\mathrm{a}}\right.$ and $\left.\mathrm{RH}\right)$ in the rearing environment was 
found. The piglets' surface temperature was affected by the type of roof, climate condition, and placement inside the farrowing pens.

\section{ACKNOWLEDGEMENTS}

To Coordination of Improvement of Higher Education (CAPES) for the research grant.

\section{REFERENCES}

ABREU, P.G; ABREU, V.M.N.; COLDEBELLA, A.; LOPES, L.S.; CONCEIÇÃO, V.; TOMAZELLI, I.L. Thermographic analysis of the superficial temperature of roofs tiles. Revista Brasileira de Engenharia Agrícola e Ambiental, Campina Grande, v.15, n.11, p.1193-1198, 2011. http://dx.doi.org/10.1590/S1415-43662011001100013.

AL-HOMOUND, M.S. Performance characteristics and practical applications of common building thermal insulation materials. Building and Environment, v. 40, p. 353-366, 2005.

doi:10.1016/j.buildenv.2004.05.013

BAÊTA, F.C.; SOUZA, C.F. Ambiência em edificações rurais: conforto animal. 2 ed. Viçosa: Ed. UFV, 2010.

BARBARI, M.; CONTI, L. Use of different cooling systems by pregnant sows in experimental pen. Biosystems Engineering, London, v.103, n.2, p.239-244, 2009.

doi.org/10.1016/j.biosystemseng.2009.02.016

BAXTER, E.M; LAWRENCE, A.B.; EDWARDS, S.A. Alternative farrowing systems: design criteria for farrowing systems based on the biological needs of sows and piglets. Animal, Boston, v. 5, n. 4, p. 580-600, 2011. doi: 5:580-600. 10.1017/S1751731110002272

BLOEMHOF, S.; WAAIJ, E.H. van der.; MERKS, J.W.M.; KNOL, E.F. Sow line differences in heat stress tolerance expressed in reproductive performance traits. Journal of Animal Science, Champaign, v. 86, p. 3330-3337, 2008. http://dx.doi:10.2527/jas.2008-0862.

BRAZILIAN ASSOCIATION OF ANIMAL PROTEIN. Brazilian pork production regions by state. São Paulo: ABPA, 2015. Disponível em: <http:// http://abpa-br.com.br/>.

BUFFINGTON, D.E.; COLLIER, R.J.; CANTON, G.H. Shed management systems to reduce heat stress for dairy cows. St. Joseph: ASABE, 1982. ( Paper, 82-4061). Disponível em: $<$ http://www.asabe.org>.

CALDARA, F.R.; SANTOS, L.S.; MACHADO, S.T.; MOI, M.; NAAS, I.A.; FOPPA, L.; GARCIA, R.G.; SANTOS, R.K.S. Piglets surface change at different weight at birth. Asian Australasian Journal of Animal Sciences, Suweon, v.27, n.3, p.431-438, 2014. Disponível em: <http://dx.doi.org/10.5713/ajas.2013.13505>.

DONG, H.; TAO, X.; LIN, J.; LI, Y.; XIN, H. Comparative evaluation of cooling systems for farrowing sows. Applied Engineering in Agriculture, St. Joseph, v.17, n.1, p.91-96, 2001. Disponível em: <http://lib.dr.iastate.edu/abe_eng_pubs/159>.

FRASER, D.; DUNCAN, I.J.H.; EDWARDS, S.A.; GRANDIN, T.; GREGORY, N.G.; GUYONNET, V.; HEMSWORTH, P.H.; HUERTAS, S.M.; HUZZEY, J.M.; MELLOR, D.J.; MENCH, J.A.; SPINKA, M.; WHAY, H.R. General principles for the welfare of animals in production systems: the underlying science and its application. The Veterinary Journal, London, v.198, p.19-27, 2013. Disponível em: 〈http://dx.doi.org/10.1016/j.tvj1.2013.06.028>.

GRANDIN, T. Recommended animal handling guidelines $\&$ audit guide: a systematic approach to animal welfare. Washington: American Meat Institute Foundation, 2013, p. 01-122. Disponível em: <http://animalhandling.org/ht/a/GetDocumentAction/i/93003>. 
INSTITUTO CAPIXABA DE PESQUISA, ASSISTÊNCIA TÉCNICA E EXTENSÃO RURAL. Programa de assistência técnica e extensão rural. Cachoeiro de Itapemirim. Brasília: MAPA, 2015.

MCGLONE, J.J.; JOHNSON, A.K.; SAPKOTA, A.; KEPHART, R.K. Establishing bedding requirements during transport and monitoring skin temperature during cold and mild seasons after transport for finishing pigs. Animals, Boston, v.4, n.2, p.241-253, 2014. Disponível em: <http://dx.doi.org/10.1016/j.ibiod.2013.12.003>.

RENAUDEAU, D.; GOURDINE, J.L.; ST-PIERRE, N.R. A meta-analysis of the effects of high ambient temperature on growth performance of growing-finishing pigs. Journal of Animal Science, Champaing, v.89, p.2220-2230, 2011. Disponível em: <http://dx.doi:10.2527/jas.20103329>.

RENAUDEAU, D.; COLLIN, A.; YAHAV, S.; BASILIO, V.; GOURDINE, J.L.; COLLIER, R.J. Adaptation to hot climate and strategies to alleviate heat stress in livestock production. Animals, Boston, v.6, n.5, p.707-728, 2012. doi: 10.1017/S1751731111002448.

SARUBBI, J.; ROSSI, L.A.; MOURA, D.J.; OLIVEIRA, R.A.; MAIA, A.P.A. Nocturnal thermal comfort in facilities for growing swines. Engenharia Agrícola, Jaboticabal, v.32. n.6, p.1034-1040, 2012. Disponível em: <http://dx.doi.org/10.1590/S0100-69162012000600004>.

SHIRAKAWA, M.A; WELE, A.P.; GAYLARDE, C.C.; LOH, K.; JOHN, V.M. Fungal and phototroph growth on fiber cement roofs and its influence on solar reflectance in a tropical climate.

International Biodeterioration \& Biodegradation, Barking, v.95, p.332-337, 2014. doi:10.1016/j.ibiod.2013.12.003

SOERENSEN, D.D.; CLAUSEN, S.; MERCER, J.B.; PEDERSEN, L.J. Determining the emissivity of pig skin for accurate infrared thermography. Computers and Electronics in Agriculture, New York, v.109, p.52-58, 2014. Disponível em: <http://dx.doi.org/10.1016/j.compag.2014.09.003>.

STATISTICAL ANALYSIS SYSTEM, SAS. Software (V.9.0). SAS/STAT 13.2 User's Guide. N.C., USA. 9284 p, 2014.

WEGNER, K.; LAMBERTZ, C.; DAS, G.; REINER, G.; GAULY, M. Climatic effects on sow fertility and piglet survival under influence of a moderate climate. Animals, Boston, p. 1-8, 2014. doi: 10.1017/S1751731114001219. PMID: 24846319.

WILLIAMS, A.M.; SAFRANSKI, T.J.; SPIERS, D.E.; EICHEN, P.A.; COATE, E.A.; LUCY, M.C. Effects of a controlled heat stress during late gestation, lactating, and after weaning on thermoregulation, metabolism, and reproduction of primiparous sows. Journal of Animal Science, v. 91, p. 2700-2714, 2013. doi:10.2527/jas.2012-6055

ZHANG, Y.; YIN, Y.; FANG, J.; WANG, Q. Pig production in subtropical agriculture. Journal of Science Food Agriculture, Chichester, v.92, n.5, p.1016-1024, 2012. doi: 10.1002/jsfa.4679 